\title{
Early marriage in Yogyakarta
}

\author{
Seri Aryati*, Sofi Yulianti, and Rahma Hardinasari \\ Department of Environmental Geography, Faculty of Geography, Gadjah Mada University, Indonesia
}

\begin{abstract}
This research explains about the beginning of marriage in the Special Region of Yogyakarta (DIY). Using descriptive analysis to analyze secondary data collected from the Central Statistics Agency (BPS) and other related institutions, data processing uses Ms. Excel Software and presented in tables, diagrams, and graphs. This study aims to determine the factors associated with early marriage in Yogyakarta and determine the impact of early marriage. In 2018, there were 312 initial marriage dispensations approved by the DIY religious court. This figure is up from 2017 with only 294 dispensations left. Early marriage is not only caused by environmental factors and economic background. This is related to the era of globalization which makes the association of children. Information that is widely disclosed if not accompanied by reasons and parental supervision will become something as dangerous as free sex. Free sex is one of the causes of early marriage, children or adolescents who do not get a strong provision will fall into promiscuity. The impact that will arise in terms of education can be a loss of opportunities for education, other than that the impact in terms of employment will certainly be hampered due to lack of education and will have an impact on the economy.
\end{abstract}

\section{Introduction}

Early marriage according to UNICEF in the Convention on the Rights of the Child is a marriage conducted by a partner who is one or all of less than 18 years. The variety of marriage patterns that can be found in a community is caused by differences in factors and habits that involve the community members [1]. The cause of trends or early marriage trends that occur is from the local area habits [2]. Early marriages have taken place in various regions in Indonesia, one of them is in the Province of Yogyakarta. The level of early marriage in Yogyakarta can be seen and analyzed from the population in a region. The results of BPS Yogyakarta Province publication data in 2018 show that the population in Yogyakarta Province in 2017 is quite large [3]. Total population based on age group and gender. Data for 2017 shows that the population of women is greater than the number of men. The population according to age group can describe the composition of the population in an area. The productive age group is between the ages of 15-64 years, while the non-productive age group is under the age of 14 years and the age is over 5 years. Age group indicators can be used to find out the expectation of unproductive population towards productive age population.

Based on the data it can be seen that the total population according to age groups and sex in Yogyakarta Province can be seen that the age of the age between 10-14 years men reaches 136,181 inhabitants and women reach 129,059 inhabitants, as well as the population with ages between 15-19 men reach 135,505 inhabitants and women reaching 130,408 inhabitants. This shows that the level of age also affects the level of early marriage that occurs in Yogyakarta [3].

Early marriage can occur due to several factors. The factors that influence early marriage according to the application of the Proceed model include knowledge, cultural beliefs, education, income, and the environment of friendship [4].The application states that there are three factors that can influence behavior such as predisposing factors (culture or tradition, beliefs, and knowledge), supporting factors (social-economic, infrastructure, education, age), and reinforcement factors (factors that can strengthen desirable behavior or influence from other people in the social environment).

Early marriage can be caused by several factors such as poverty, economic and educational constraints, as well as tradition and religion [5]. Geographical areas can also affect early marriages. Residents who live in rural areas tend to have more early marriage. This can be caused by the lack of access to education and available information, attachment to customs and culture, and the low economy which increasingly affects the level of early marriages that occur [6]. Early marriages that occur can cause certain effects, especially in women. Women who are married at a young age (10-19 years old) face almost five times higher risk of dying during pregnancy and

\footnotetext{
* Corresponding author: seri.aryati@ugm.ac.id
} 
childbirth compared to women who are mature (20-24 years) [7].

At this time the issue of early marriage back again to the perception of each individual, and parents with children. Families in Iran who have positive perceptions and attitudes towards early marriage based on existing traditional values, for example parents will marry off their daughters to prevent sexual behavior outside of marriage because easy to get information that stimulates teenagers through porn films [8]. Liberalization is increasing which results in attitudes towards sexuality in culture increasingly popular through access to digital media and virtual technology and among peers [9]. Parents' perceptions about early marriage in Iran differ from the conditions that occur in Yogyakarta where early marriage often occurs because of promiscuity, promiscuity can occur because one of them from an educational background. Impact of educational background will cause domestic violence by the husband to his wife to be greater than married couples in adulthood and the limited use of maternal health services including during pregnancy to control contraceptive use [10]. Early marriage is very influential on the psychology of someone who engages in early marriage as their basic human rights are not provided, because some psychological and physiological problems occur usually leading to divorce or suicide [11].

Based on these data it can be seen that the total population according to age group and gender in Yogyakarta Province can be seen that between 10-14 years old men reach 136,181 residents and women reach 129,059 residents, as well as residents with ages between 15-19 men reach 135,505 inhabitants and women reach 130,408 inhabitants. This shows that the age level also affects the level of early marriage that occurs in Yogyakarta.

\section{Data and Method}

This research is a quantitative study that is analyzed by quantitative descriptive analysis. Yogyakarta Special Region (DIY) as the study area and the province as the unit of analysis. The scope of the study includes an analysis of early marriage and its trends. Furthermore, it is analyzed by secondary data which can still be covered by the data. Data was collected using the literature study method from BPS data and supporting data from other relevant institutions. The following data governs this research:

1. National Socio-Economic Survey Data (SUSENAS) 2013-2017

2. Indonesian Demographic and Health Survey Data 2017

3. Yogyakarta Special Region Data in Figures 2018

\subsection{Data analysis method}

The method used for data analysis in this study is quantitative descriptive analysis. This method is used based on the power used, namely data in the form of numbers (quantitative). The method of data analysis is carried out with the aim of finding out the level of early marriage that occurs and the factors that influence the occurrence of early marriage in Yogyakarta. Presentation of data for analysis in the form of tables, diagrams, and graphs in accordance with the conditions of the data.

\section{Result and Discussion}

The normal age for a marriage for men is 25 years and for women is 21 years, but now there are problems in early marriage [4]. One of the problems that will arise is due to the age of the first marriage of female residents who are still children, which is around 10 years, which will affect the fertility level which ultimately affects the population of an area.This is caused because the younger the age of the first marriage of the female population will the longer the reproductive period which causes a very high birth rate. Yogyakarta Province is one of the provinces in Indonesia which has the age of first marriage for women aged from 10-16 years, that age is arguably the age of children and is too early for marriage. The following Table 1. Percentage of Women 10 Years and Over by Marriage Status and Age Group in Yogyakarta Province in 2013-2017.

Table 1. Percentage of Women 10 Years and Over by Marital Status and Age Group in Yogyakarta Province in 2013-2017

\begin{tabular}{|c|c|c|c|c|c|}
\hline \multirow{2}{*}{ Year } & \multicolumn{4}{|c|}{ Age of First Marriage } & \multirow{2}{*}{ Total } \\
\cline { 2 - 5 } & $<\mathbf{1 6}$ & $\mathbf{1 7 - 1 8}$ & $\mathbf{1 9 - 2 4}$ & $\mathbf{2 5}+$ & \\
\hline 2013 & 7.26 & 18.30 & 51.99 & 22.44 & 100 \\
\hline 2014 & 7.61 & 17.66 & 53.06 & 21.67 & 100 \\
\hline 2015 & 2.09 & 6.76 & 75.85 & 15.30 & 100 \\
\hline 2016 & 7.34 & 14.28 & 54.16 & 24.23 & 100 \\
\hline 2017 & 4.55 & 13.59 & 55.10 & 26.76 & 100 \\
\hline
\end{tabular}

The results of the above data indicate that the vulnerable age at the first marriage 19-24 has the highest number compared to other vulnerable ages at the first marriage. When viewed from the trends for each vulnerable age at the first marriage each year has differences with each other, but for vulnerable ages at the first marriage less than 16 years, $17-18$ years and 25 years and over has decreased in 2015. Conversely for age marriages vulnerable first year 19-24 which increased in 2015 , even in that year the vulnerable age of first marriage 19-24 had the highest value compared to the previous year and the following year [12].

In this case it can be said that at the first marriage the age of 19-24 years had succeeded in controlling access to existing media, sex education needs to be done early to provide moral "filters" or "strongholds" to protect themselves towards the development of increasingly sophisticated technology [9]. This shows that from previous studies have in common in providing good morals in the face of technological development and from the present study there are many first marriages at the age 
of 19-24 years. In 2016 and 2017 at the age of 19-24 the first marriage was even higher.

Early marriages examined in this study were at a vulnerable age of first marriage less than 16 years in Yogyakarta using Susenas data from March 2013 to March 2017. As shown in Figure 1 below:

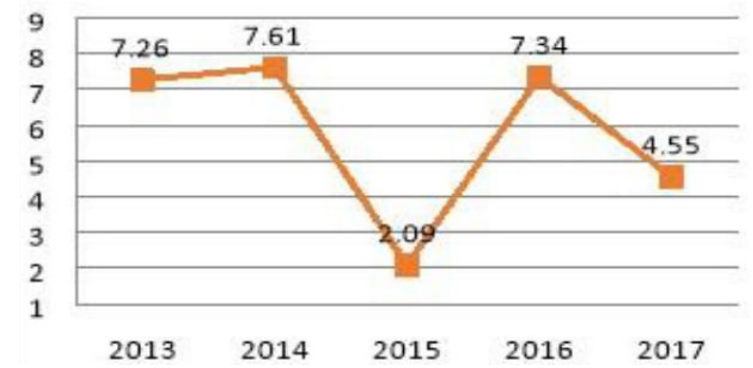

Fig. 1. Percentage of Women 10-16 Years and Over According to Marital Status in Yogyakarta Province 2013-2017

Based on the graphic image above, the results obtained in the form of trends that occur at vulnerable ages 10-16 years experience an up and down trend, in 2013 to 2014 experienced an increase and a very drastic decline from the value of 7.61 in 2014 to 2.09 in 2015 , then increased in 2016 and decreased again in 2017 which is not too significant. This proves that in 2013 to 2014 and 2016 early marriage at the age of vulnerable first marriages of 10-16 years had increased [13].This increase in early marriage data can be caused by the level of education and the level of welfare of the population in several districts in Yogyakarta Province which are still lagging behind. As for the data that declined in 2015, this could be due to the population already aware of the importance of education.

Unlike early marriage nationally when viewed using data from the Indonesian Demographic and Health Survey, early marriage is classified from the age of first marriage to 15 years and over. Like Table 2 below:

Table 2. Percentage of Women 15-49 According to Marital Status and Age Groups in Indonesia in 2017

\begin{tabular}{|c|c|c|c|c|c|}
\hline \multirow{2}{*}{ Age } & \multicolumn{5}{|c|}{ First Marriage Age } \\
\cline { 2 - 6 } & $\mathbf{1 5}$ & $\mathbf{1 8}$ & $\mathbf{2 0}$ & $\mathbf{2 2}$ & $\mathbf{2 5}$ \\
\hline $15-19$ & 10.5 & $\mathrm{Na}$ & $\mathrm{Na}$ & $\mathrm{Na}$ & $\mathrm{Na}$ \\
\hline $20-24$ & 3.7 & 30.8 & 63.7 & $\mathrm{Na}$ & $\mathrm{Na}$ \\
\hline $25-29$ & 2.7 & 20.2 & 41.3 & 63.7 & 87.2 \\
\hline $30-34$ & 4.7 & 23.4 & 40.7 & 58.5 & 79.7 \\
\hline $35-39$ & 5.8 & 25.9 & 44.3 & 61.8 & 79.2 \\
\hline $40-44$ & 8.5 & 29.4 & 46.8 & 62.3 & 80.1 \\
\hline $45-49$ & 12.3 & 33.6 & 51.2 & 6.2 & 81.0 \\
\hline
\end{tabular}

The percentage data above shows that at the age of first marriage 15-19 years with the age of first marriage 15 has a value of 10.5 which means that the value is higher than the number of early marriages that occurred in Yogyakarta Province in 2017 which amounted to 4.55 [14].

The high rate of early marriage when viewed nationally can be caused because Indonesia is an archipelagic country that has a variety of tribes and cultures, so it can be ascertained that culture or tradition in the local community is very influential because early marriage occurs mostly in communities where there are a culture that justifies early marriage, and low levels of education, and consequently poverty has increased [15].

In general, early marriage in Yogyakarta can be seen from the data on sex and marital status, as in table 3 below:

Table 3. Early Marriage of Yogyakarta in 2017

\begin{tabular}{|l|c|c|c|c|c|}
\hline \multirow{2}{*}{ Gender } & \multicolumn{4}{|c|}{ Marital Status } & Total \\
\cline { 2 - 6 } & Single & Marry & $\begin{array}{c}\text { Divor } \\
\text { ced }\end{array}$ & $\begin{array}{c}\text { Death } \\
\text { Divorce }\end{array}$ & \\
\hline Male & 35.40 & 60.16 & 1.34 & 3.10 & 100 \\
\hline Women & 25.77 & 59.71 & 2.60 & 11.92 & 100 \\
\hline $\begin{array}{l}\text { Male + } \\
\text { Women }\end{array}$ & 30.51 & 59.94 & 1.98 & 7.57 & 100 \\
\hline
\end{tabular}

Based on the data above shows that the sex of men is higher in marital and unmarried marital status compared to women with lower values in unmarried and married status [13]. This can be due to unmarried men who are still preoccupied with the world of work without any age restrictions, whereas the average woman if she enters mature age immediately marries because there are many considerations when deciding to marry at an overly mature age, as will affect fertility and etc.

The status of divorced marriage and divorce of women is higher than that of men, this is due to the number of early marriages in Yogyakarta with residents who are not ready to get married but because of promiscuity that causes pregnancy outside of marriage inevitably will soon be married, but if it is not accompanied by a prepared mentality, there will often be problems in the household that will cause divorce. Marriages are conducted if men reach the age of 19 years and women 16 years with the provisions that there must be permission from parents, if there is a deviation from the Act, it is certain that early marriage in Yogyakarta will be even higher [16].

Early marriage can occur due to several factors such as poverty, economic problems. Education, as well as tradition and religion [5]. The location of residence can also affect the level of early marriage that occurs. People who live in rural areas tend to have more early marriages than people who live in urban areas. The lack of access to education and information obtained, the presence of customary and cultural ties, and the still low economy can affect the level of early marriage that occurs [6]. This can happen in Yogyakarta, which still has some areas that are still lagging behind or can be classified as rural areas. The factor of early marriage in Yogyakarta occurs because of low economic background in several districts in Yogyakarta. As table 4 which shows the population 15 years and over who work according to Regency / City, Gender, and Village / City. 
Table 4. Population 15 Years and Over Who Work by Regency / City, Gender, and Village / City.

\begin{tabular}{|c|c|c|c|c|}
\hline \multirow{4}{*}{$\begin{array}{c}\text { Num } \\
\text { ber }\end{array}$} & \multirow{4}{*}{ District / City } & \multicolumn{3}{|c|}{ Regional Classification } \\
\hline & & \multicolumn{3}{|c|}{ City } \\
\hline & & \multicolumn{3}{|c|}{ Gender } \\
\hline & & Male & Women & Total \\
\hline \multicolumn{5}{|c|}{ Distric } \\
\hline 1 & Kulon Progo & 37,317 & 28,767 & 66,084 \\
\hline 2 & Bantul & 268,070 & 208,500 & 476,570 \\
\hline 3 & $\begin{array}{c}\text { Gunung } \\
\text { kidul }\end{array}$ & 33,175 & 23,282 & 56,457 \\
\hline 4 & Sleman & 348,796 & 266,046 & 614,842 \\
\hline \multicolumn{5}{|l|}{ City } \\
\hline \multirow[t]{2}{*}{1} & Yogyakarta & 111,395 & 102,196 & 213,591 \\
\hline & $\begin{array}{c}\text { Yogyakarta } \\
\text { Province }\end{array}$ & 798,753 & 628,791 & $1,427,544$ \\
\hline \multirow{4}{*}{$\begin{array}{c}\text { Num } \\
\text { ber }\end{array}$} & \multirow{4}{*}{ District / City } & \multicolumn{3}{|c|}{ Regional Classification } \\
\hline & & \multicolumn{3}{|c|}{ City } \\
\hline & & \multicolumn{3}{|c|}{ Gender } \\
\hline & & Male & Women & Total \\
\hline \multicolumn{5}{|c|}{ Distric } \\
\hline 1 & Kulon Progo & 92,116 & 81,342 & 173,458 \\
\hline 2 & Bantul & 32,612 & 32,330 & 64,942 \\
\hline 3 & Gunungkidul & 197,457 & 168,477 & 365,934 \\
\hline 4 & Sleman & 8,668 & 12,622 & 21,290 \\
\hline \multicolumn{5}{|l|}{ City } \\
\hline \multirow[t]{2}{*}{1} & Yogyakarta & 0 & 0 & 0 \\
\hline & $\begin{array}{c}\text { Yogyakarta } \\
\text { Province }\end{array}$ & 330,853 & 294,771 & 625,624 \\
\hline
\end{tabular}

Based on the data above shows that the regency whose population works in the highest urban area classification of Sleman regency with a value of 348,796 for men and 266,046 for women, then followed by Bantul regency. This is due to the fact that the two regencies are directly adjacent to the City of Yogyakarta, which is the economic center of Yogyakarta Province. It is different from the condition of village area classification which has the highest value in Gunungkidul Regency for 197,457 for men and 168,477 for women. Whereas for the city of Yogyakarta it has a value of 798,753 for men and 628,791 for women, this value is higher than the value of workers with a village area classification of 330,853 for men and 294,771 for women. Men are more dominant who work, this is because men are family heads who have to meet the needs of their families [17].

Early marriage has become a phenomenon that occurs in several regions in Indonesia. Early marriage in an area occurs because of the norms that apply in traditional societies with the existence of social economic relations between generations. Early marriage can occur due to various factors. Variables that influence early marriage include education, employment, and poverty (economic factors). The variables of early marriage can be explained as follows:

\subsection{Highest Education Completed}

Based on Sakernas data, population 15 years and over according to the highest level of education completed shows that the number of workforce is greater than the number of non-workforce. The population of the workforce with the highest level of education who completed the most at the Vocational High School level was 436,844 people, while the number of the workforce with levels of education below elementary, elementary, junior high, and senior high schools was also quite large. The labor force with the last education completed at the diploma and university level is the least. This can affect the quality of the workforce which will affect the type of work chosen. A workforce with low education can also affect the level of early marriage that occurs in Yogyakarta. Data on the number of people belonging to the labor force with no last education completed at the diploma and university level is quite low. The latest education completed both in the workforce population group and not the workforce can influence the mindset of the community which later becomes a reference in social life, including regarding early marriage that occurs in Yogyakarta.

Table 5. Population Aged 15 Years and Over by Highest Education Completed and Types of Activities Over the Last Week in Yogyakarta Province in 2017

\begin{tabular}{|l|r|r|r|}
\hline \multicolumn{1}{|c|}{$\begin{array}{c}\text { Highest } \\
\text { Education }\end{array}$} & \multicolumn{2}{|c|}{ Labor } & \multirow{2}{*}{ Total } \\
\cline { 2 - 3 } & Workforce & $\begin{array}{c}\text { Not the } \\
\text { Work } \\
\text { Force }\end{array}$ & \\
\hline $\begin{array}{l}\leq \text { Elementary } \\
\text { School }\end{array}$ & 303,509 & 150,551 & 454,060 \\
\hline $\begin{array}{l}\text { Elementary } \\
\text { School }\end{array}$ & 348,609 & 100,942 & 449,551 \\
\hline $\begin{array}{l}\text { Junior high } \\
\text { school }\end{array}$ & 353,179 & 221,957 & 575,136 \\
\hline $\begin{array}{l}\text { Senior High } \\
\text { School }\end{array}$ & 335,156 & 205,413 & 540,569 \\
\hline $\begin{array}{l}\text { Vocational } \\
\text { High School }\end{array}$ & 436,844 & 101,512 & 538,356 \\
\hline Diploma & 97,561 & 20,044 & 117,605 \\
\hline University & 242,329 & 42,598 & 284,927 \\
\hline Total & $2,117,187$ & 843,017 & $2,960,204$ \\
\hline
\end{tabular}

Data on population aged 15 years and over who are included in the workforce according to the highest education completed and city / village shows that 
populations 15 years and over are found more in cities than in villages. The number of population aged 15 years and over with the last education completed at the diploma and university level is relatively lower than other levels of education in the city or village. The number of population aged 15 years and over with the most recent education completed at the elementary school level and below, while the population with the last education completed at the junior high school, senior high school and vocational high school are also classified as many but not as much as the school level basic below $[18,19]$. This shows that the quality of education of the population 15 years and over in Yogyakarta is not optimal and not many have completed their education at the diploma and university level. The low level of education completed by the population can affect the level of early marriage in the area. Low education will affect the work and income earned. Jobs and income will affect the economy of the community. Low economic conditions will affect the mindset that marrying off children is one solution to overcome these problems. The mindset of the community will affect the level of early marriage that occurs in Yogyakarta Province.

Table 6. Population Aged 15 Years and Over Included in the Labor Force According to Highest Education Completed and City / Village During the Past Week in Yogyakarta Province August 2017

\begin{tabular}{|l|r|r|r|}
\hline \multicolumn{1}{|c|}{$\begin{array}{c}\text { Highest } \\
\text { Education }\end{array}$} & \multicolumn{2}{|c|}{ Regional Classification } & \multicolumn{1}{l|}{ Total } \\
\cline { 3 - 3 } $\begin{array}{l}\text { Elementary } \\
\text { School }\end{array}$ & 354,273 & 297,845 & \multicolumn{1}{c|}{652,118} \\
\hline $\begin{array}{l}\text { Junior high } \\
\text { school }\end{array}$ & 212,103 & 141,076 & 353,179 \\
\hline $\begin{array}{l}\text { Senior High } \\
\text { School }\end{array}$ & 273,205 & 61,951 & 335,156 \\
\hline $\begin{array}{l}\text { Vocational } \\
\text { High }\end{array}$ & 342,946 & 93,898 & 436,844 \\
School & 83,682 & 13,879 & 97,561 \\
\hline Diploma & 214,804 & 27,525 & 242,329 \\
\hline University & $1,481,013$ & 636,174 & $2,117,187$ \\
\hline Total & & & \\
\hline
\end{tabular}

\subsection{Profession}

Work is one of the factors that can influence the level of early marriage. Based on the data published by BPS in the Province of DIY in Figures 2018, it can be seen that the population aged 15 years and over with agricultural, plantation, forestry, hunting and fishery jobs, as well as trade, restaurants, and accommodation services have the largest percentage among the main employment other. This shows that the population aged 15 years and over in Yogyakarta Province with the main jobs are agriculture, plantation, forestry, hunting and fisheries, as well as trade, restaurants, and accommodation services still dominate in the area [20]. The work tends to be less in improving the economy of the community so that people in Yogyakarta can be said to still have a low economy. Low economic factors can lead to the mindset of people, especially rural communities that marrying children is considered to be able to overcome the existing economic problems. That mindset is one that influences the level of early marriage that occurs in Yogyakarta Province.

\subsection{Poverty}

One of the factors of early marriage in Yogyakarta is poverty. This can happen because some residents believe that marrying off their children will help the family's economy. Based on data from the official statistical news for 2017, the results shown in Figure 2 below:

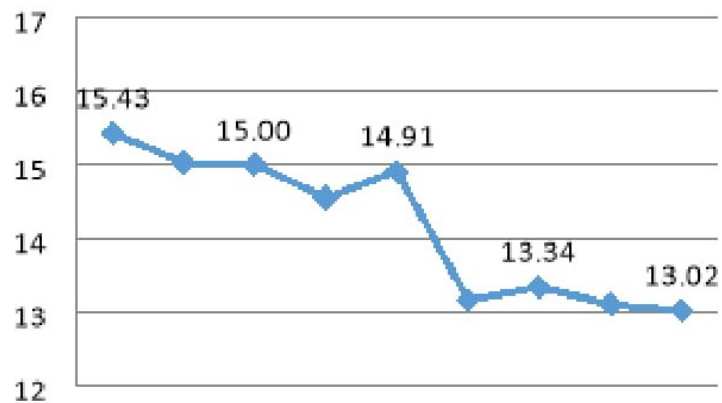

Fig. 2. Percentage of Poor Population in Yogyakarta Special Region March 2013 - March 2017

Based on the above data it is found that from 2013 to 2017 Yogyakarta poverty has an up and down trend, where in March 2013 to September 2014 has decreased then rose again in March 2015 and finally until 2017 has decreased and is associated with in 2017 for age of first marriage in Yogyakarta has decreased [21]. This can be said that the government succeeded in overcoming poverty that occurred in Yogyakarta. Like Figure 3 below which shows the percentage of poor people in Yogyakarta.

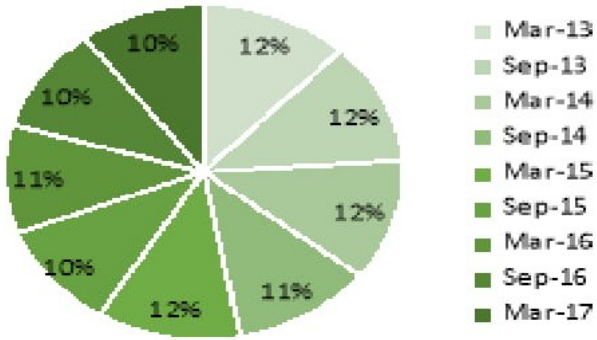

Fig. 3. Percentage of Poor Population in Yogyakarta Special Region March 2013 - March 2017

The development of the era in the era of globalization requires expertise to be able to meet their daily needs, if they cannot follow the era of globalization, they will be left behind and will certainly have difficulty meeting their daily needs. Based on the diagram above poverty decreases every year, although it occasionally experiences a spike. It can be said that the population of Yogyakarta has been able to improve the economy at the household level. But if we look closely at early marriage 
it is not only caused by environmental factors and economic background. This is related to the era of globalization that makes the association of children, adolescents become affected by the outside world because of the opening of information that can be accessed via the internet on mobile phones. Widely disclosed information if not accompanied by reason and parental supervision will become something as dangerous as free sex. This free sex can cause premature marriages among children and adolescents. Free sex can occur because children have entered promiscuity.

\section{Conclusions}

1. Early marriage is not only caused by environmental factors and economic background. This is related to the era of globalization that makes the association of children, adolescents become affected by the outside world because of the opening of information that can be accessed via the internet on mobile phones. Widely disclosed information if not accompanied by reason and parental supervision will become something as dangerous as free sex. This free sex can cause premature marriages among children and adolescents.

2. The impact arising from early marriage in terms of health that will affect fertility rates which ultimately affect the population of an area. This is due to the young age of the first marriage of the female population will the longer the reproductive period which causes a very high birth rate. The impact that will arise in terms of education that can be the loss of opportunities for education. Other than that the impact in terms of employment will certainly be hampered because of low education and will have an impact on the economy.

This paper is part of the Independent Geography Faculty Lecturer Grant, UGM entitled "Early Marriage in Yogyakarta" which was funded in 2020 .

\section{REFRENCES}

1. UNICEF. "Early Marriage: A Harmfull Traditional Practice, A Statistical Exploration" (2006)

2. J. M. Adams and W. H. Jones. The Conceptualization of Marital Commitment: An Integrative Analysis. Journal of Personality and Social Psychology, 72(5), 1177-1196 (1997)

3. BPS (Statistics Indonesia). Provinsi Yogyakarta Dalam Angka: Jumlah Penduduk Menurut Kelompok Umur dan Jenis Kelamin di Provinsi Daerah Istimewah Yogyakarta Tahun 2017. Yogyakarta: Badan Pusat Statistik (2018)

4. E. S. Sulaeman. Model dan Teori Perilaku Kesehatan, Konsep dan Aplikasi. Surakarta: Universitas Sebelas Maret Press (2016). In Bahasa

5. A. D. Judiasih, S. Suparto, A. Afriana, and D. Yuanitasari, Women, Law And Policy: Child Marriage Practices In Indonesia. Jurnal Notariil,
Vol. 3, No. 1, Mei 2018, 47-55. Bandung: Universitas Padjajaran (2018)

6. S. Windiarti and Besral. Determinants Of Early Marriage In Indonesia. Proceedings of International Conference on Applied Science and Health (No. 3, 2018). Depok : Universitas Indonesia (2018)

7. N. A. Wijayati, R. B. Soemanto, E. P. Pamungkasari. Socioeconomic and Cultural Determinants of Early Marriage in Ngawi, East Java: Application of Precede-Proceed Model. Journal of Health Promotion and Behaviour (2017), 2(4): 302-312. Surakarta : Universitas Sebelas Maret (2017)

8. S. Montazeri, M. Gharacheh, N. Mohammadi, J. A. Rad, H. E. Ardabili. Determinants of Early Marriage from Married Girls' Perspectives in Iranian Setting: A Qualitative Study. Journal of Environmental and Public Health, 1(8) (2016)

9. T. Webster Wright. Understanding the Ties that Bind: Early Marriage in Yogyakarta. Journal Indonesian Feminist, 3(1) 79-85 (2015)

10. M. Delprato, K. Akyeampong, R. Sabates, J. Hernandez-Fernandez. On teh Impact of Early Marriage On Schooling Outcomes in Sub-Saharan Africa and South West Asia. Internasional Journal of Educational Development, 44: 42-55 (2015)

11. A. J. Gage. Association of Child Marriage with Suicidal Thoughts and Attempts Among Adolescent Girls in Ethiopia. Journal of Adolescent Health (2013)

12. Susenas Maret 2013-2017. Presentase Wanita 10 Tahun ke Atas Menurut Status Perkawinan dan Kelompok Umur di Provinsi Yogyakarta Tahun 20132017. Yogyakarta : Badan Pusat Statistik (Statistics Indonesia). (2017)

13. Susenas Maret 2013-2017. Pernikahan dini Provinsi D.I.Yogyakarta 2017. Yogyakarta : Badan Pusat Statistik (Statistics Indonesia). (2017).

14. Survey Demografi Kesehatan Indonesia (SDKI). Presentase Wanita Kawin Umur 15-49 Menurut Umur Kawin Pertama Dan Menurut Umur, Indonesia 2017. Jakarta : BKKBN, BPS, Kementerian Kesehatan, dan ICF Internasional. (2017)

15. Sangaji, S. Islamiawati. Analisis Dampak Pernikahan Dini Terhadap Kesehatan Reproduksi Pada Remaja Putri Di Kecamatan Gamping Kabupaten Sleman. Skripsi. Fakultas Ilmu Kesehatan. UNISA : Yogyakarta (2017). In Bahasa

16. Undang-Undang Tentang Perkawinan, UU Nomor 1 Tahun 1974 LN Nomor 1 Tahun 1974, TLN No.3019. (1974)

17. BPS (Statistics Indonesia). Daerah Istimewa Yogyakarta Dalam Angka 2018 : Penduduk 15 Tahun ke Atas yang bekerja menurut Kabupaten/Kota, Jenis Kelamin, dan Desa/kota. Yogyakarta: BPS Provinsi DIY (2018)

18. Survei Angkatan Kerja Nasional Agustus 2017. Penduduk Berumur 15 Tahun ke Atas Menurut Pendidikan Tertinggi yang Ditamatkan dan Jenis Kegiatan Selama Seminggu yang Lalu di Provinsi 
DIY Tahun 2017. Yogyakarta : Badan Pusat Statistik (Statistics Indonesia ) (2017)

19. Survei Angkatan Kerja Nasional Agustus 2017. Penduduk Berumur 15 Tahun ke Atas Yang Termasuk Angkatan Kerja Menurut Pendidikan Tertinggi yang Ditamatkan dan Kota/Desa Selama Seminggu yang Lalu di Provinsi DIY Agustus 2017. Yogyakarta: Badan Pusat Statistik (2017)

20. BPS (Statistics Indonesia). Provinsi DIY Dalam Angka 2018 : Penduduk Berumur 15 Tahun ke Atas yang Bekerja Selama Seminggu yang Lalu Menurut Lapangan Pekerjaan Utama dan Jenis Kelamin di Provinsi D. I. Yogyakarta Tahun 2017. Yogyakarta : Badan Pusat Statistik. (2018)

21. Susenas Maret 2013-2017. Persentase Penduduk Miskin Di Daerah Istimewa Yogyakarta Maret 2013 - Maret 2017. Yogyakarta : Badan Pusat Statistik. (2017) 